\title{
Assessing Student Reflection in a Malaysian Classroom
}

\author{
Marianne Estabella Fung ${ }^{1}$ \\ May Siaw-Mei Liu ${ }^{2}$ \\ ${ }^{1,2}$ MARA University of Technology, Sabah, Malaysia \\ ${ }^{2} E m a i l:$ mef@sabah.uitm.edu.mv \\ ${ }^{2}$ Email: mavliu215@gmail.com
}

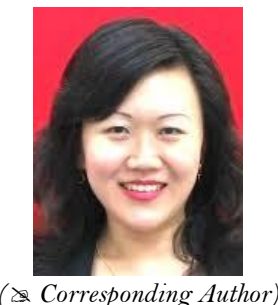

( Corresponding Author)

\begin{abstract}
Studies into reflective thinking in education have proposed a link between reflection and transformative learning. It is thus important for classroom practitioners to be able to identify whether students are reflecting on the subject matter of an academic course that they are undertaking. To this end, reflective journals can provide valuable information regarding the emotional and cognitive processes of the students. This study seeks to identify the level of reflective thinking attained by final year university students in Sabah, Malaysia, who have enrolled in an English for Specific Purposes course. As a preliminary study of the population, degree students from MARA University of Technology Malaysia were sampled and their reflective journals were analysed. The classification was done using a modified coding scheme proposed by past key researchers to classify students into the three categories of non-reflectors, reflectors, and critical reflectors. The results of this study can provide useful insights to course instructors.
\end{abstract}

Keywords: Reflective thinking, Reflective journals, English as a second language.

Citation | Marianne Estabella Fung; May Siaw-Mei Liu (2018). Assessing Student Reflection in a Malaysian Classroom. Asian Journal of Education and Training, 4(4): 272-279.

History:

Received: 4. July 2018

Revised: 2 August 2018

Accepted: 9 August 2018

Published: 13 August 2018

Licensed: This work is licensed under a Creative Commons

Attribution 3.0 License (oc)

Publisher:Asian Online Journal Publishing Group
Contribution/Acknowledgement: Both authors contributed to the conception and design of the study.

Funding: This study received no specific financial support.

Competing Interests: The authors declare that they have no conflict of interests.

Transparency: The authors confirm that the manuscript is an honest, accurate, and transparent account of the study was reported; that no vital features of the study have been omitted; and that any discrepancies from the study as planned have been explained.

Ethical: This study follows all ethical practices during writing.

\section{Contents}

1. Introduction

2. Theoretical Framework

4. Results and Discussion

5. Conclusion 


\section{Introduction}

It has long been debated whether the kind of knowledge that academic training provides to learners at universities is the kind of competence required in professional practice (Schon, 1983; Kayapinar, 2016). One important component of critical thinking which has been linked to workplace competence is a person's ability to reflect on what was learned (Basol and Gencel, 2013; Chittooran, 2015). In fact, past literature has found a link between learners' ability to reflect on their studies and their level of competence in the workplace. This, in turn, can lead to the transformation of thinking (Mezirow, 2000). It is believed that if a student is able to reflect upon what is taught academically in a university environment, it can bridge the divide between theory and practice (Lyons, 2010; Casey, 2013).

According to literature, if a university is able to produce reflective thinkers as opposed to mere academically competent graduates, it will mean that the university has produced graduates who are prepared for the challenges of professional work. For this reason, reflective thinking has been touted as an important learning goal in higher education (Bell et al., 2011). Nevertheless, training students to become reflective thinkers has become "one of today's fundamental challenges in education” (Naghdipour and Emeagwali, 2013). To this end, various studies have been conducted on the subject of reflective thinking using different samples from different locations around the world. For instance, Wium and Plessis (2016) conducted a study on students in South Africa; Kayapinar (2016) examined in-service teachers in the Middle East, Abednia et al. (2013) conducted a study on students taking a course on second language teaching methodology in Tehran, Iran; Naghdipour and Emeagwali (2013) focused on students studying English as a Foreign Language in Cyprus; Forneris and Peden-McAlpine (2007) obtained their sample from novice nurses in the USA; and Wong et al. (1995) did their study on nursing students at HK Polytechnic University. To date, however, results assessing the level of reflective thinking in Malaysian students have been scarce. Just how reflective are the students at a typical Malaysian university today? Most academic practitioners are unable to answer this question because studies into reflective thinking levels of specific groups of students in a Malaysian context have been rare. Yet, it is a crucial area which needs to be understood in order to answer some of the pertinent questions raised by society today especially with regard to why some graduates are unable to perform at the workplace.

This study aims to fill that gap by assessing the level of reflective thinking in students taking an English for Specific Purposes (ESP) course in an undergraduate programme of study at the Sabah branch of MARA University of Technology in Malaysia. The research question which guides this study is, "What level of reflective thinking have the students at the Sabah branch of MARA University of Technology attained?" It is necessary to first understand if students are reflecting upon their learning experience before instructors can come up with instructional strategies to aid these students.

\section{Theoretical Framework}

Studies into reflective thinking can be traced back to the early thirties when Dewey (1933) defined reflective thought as the "active, persistent and careful consideration of any belief or supposed form of knowledge in the light of the grounds that support it, and the further conclusions from which it tends" and proposed that it was an important skill which educators should aim to instill in learners (Kember et al., 2008; Dyment and O'Connell, 2011; Chittooran, 2015). In recent years, education practitioners and researchers alike have not only welcomed the concept of reflective thinking but have also studied it extensively (Abednia et al., 2013).

Notable studies in the area of reflective thinking include the oft-cited works of Schon (1983); Boud et al. (1985) and Wong et al. (1990;1991). Schon (1983) was one of the researchers who highlighted that the kind of knowledge which academic training provides to graduates may not be the kind of competence required in professional practice. Based on his work, Schon (1983) felt that there was a mismatch of "theory vs practice" in terms of the kinds of graduates which academic institutions were producing (Lyons, 2010). Boud called the kinds of learning in most academic institutions as "the relatively passive norms of conventional teaching" (Boud, 1994).

Before any discussions on reflection can be made, it is necessary to examine how reflection fits into the learning process. Boud (1994) believed that all learning draws upon prior experience which will determine the intent a learner brings to the learning process. This learning process is an active process which happens within the "learning milieu, i.e. the social, psychological and material environment in which the learner is situated" (Boud, 1994). A three-stage model of learning from experience is proposed by Boud (1994) and this is depicted in Figure 1.

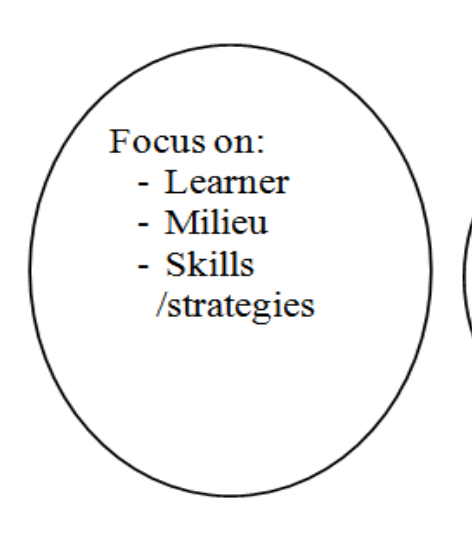

PREPARATION

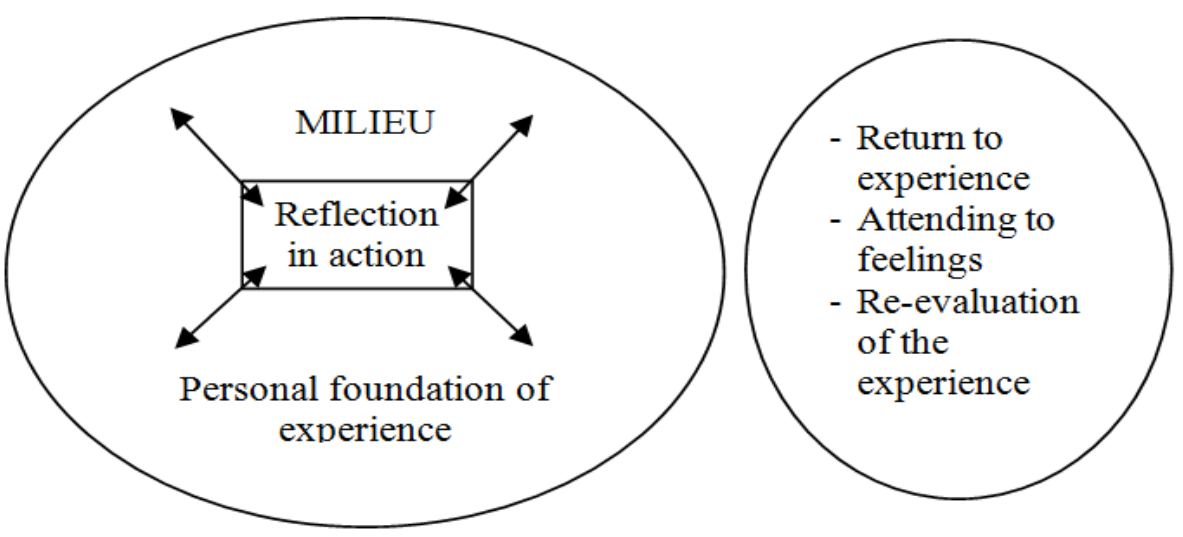

EXPERIENCE

Figure-1. Model of learning from experience 
Boud's (1994) model consists of three stages, which are, (i) the preparation stage (activities and experiences prior to the event), (ii) the experience stage (activities or experiences during the event), and (iii) the reflective processes stage (activities or experiences after the event). The preparation stage is the part where planning is made to ensure that learners can optimise their learning. It takes into account characteristics of the learner, the milieu (or social, psychological, and material environment), as well as the skills and strategies available for learning. During the 'experience' stage, the learner engages with the milieu and this produces the learning experience. The three elements of 'noticing', 'intervening', and 'reflection in action' happen during the learning experience stage as the learner draws upon his/her personal foundation of experience and intent. Boud (1994) was of the view that crucial learning happens after an event as learners are now not distracted by the milieu since "some aspects inevitably take time" and after an event, learners should be more able to "view particular events in a wider context". The three main reflective elements which happen after an event are 'return to experience', 'attending to feelings', and 're-evaluation of experience'. A summary of these three elements is provided in Table 1.

Boud (1994) has provided a useful framework to situate the reflective thinking process. Other researchers have also contributed to the literature in this area and some have gone a step further to define critical reflection and link it with transformative learning. According to Wong et al. (1990) reflection is a higher-order mental process by which a person uses existing beliefs to interpret a situation, make inferences, discriminate, evaluate, and judge. Just like Boud (1994), Wong et al. (1990) was of the view that existing beliefs or prior learning is drawn upon to evaluate and critique or solve a problem. However, to Wong et al. (1990) critical reflection goes a step further and involves questioning those prevailing beliefs and other existing presuppositions and perspectives. The process of critical reflection is often accompanied by strong emotions but critical thinking is the vehicle which leads to transformation of thinking or paradigm shifts (Wong et al., 1990). When a paradigm shift happens, transformative learning then takes place. In Mezirow's (2000) words, "Transformative learning refers to the process by which we transform our taken-for-granted frames of reference (meaning perspectives, habits of mind, mindsets) to make them more inclusive, discriminating, open, emotionally capable of change and reflective so that they may generate beliefs and opinions that will prove more true or justified to guide action". Thus, reflection is an essential part of the process towards transformative learning. Along the same lines, Wong et al. (1995) see the transformation as the outcome of reflection as they believe that "the outcomes of reflection include a new way of doing something, the clarification of an issue, the development of a skill or the resolution of a problem. New perspectives on experience or changes in behaviour are developed".

Due to increased interest in the area, there is a need to create, evaluate, and re-evaluate models and instruments to code and classify reflective thinking practices. Some researchers have felt that there is a lack of proper instruments to assess reflective thinking and that existing tools and models do not appear to reflect a single definition which is universally accepted by the discourse community (Naghdipour and Emeagwali, 2013).

Despite the lack of agreement, existing models and coding mechanisms are still useful as a starting point to both researchers and practitioners when trying to identify the presence and levels of learners' reflective thinking. There are a few notable models of reflective thinking available today. Other than the elements of reflective processes proposed by Boud (1994), Kember (1999) had also proposed a framework to evaluate reflective processes. The initial seven-category framework of Kember (1999) consisted of the following categories, (i) habitual action, (ii) introspection, (iii) thoughtful action, (iv) content reflection, (v) process reflection, (vi) content and process reflection, and (vii) premise reflection. In a later development, however, it was felt that the seven categories were "too fine-grained" (Kember et al., 2008) and thus, a newer four-category scheme for coding and assessing learners' level of reflection was proposed, which included (i) habitual action, (ii) understanding, (iii) reflection, and (iv) critical reflection (Kember et al., 2008). Table 1 provides a summary of this model.

Wong et al. (1995) also proposed a coding scheme to assess reflective thought which they based on earlier models by Boud et al. (1985) and Wong et al. (1991). In their model, they felt that the element "returning to experience" (Wong et al., 1995) need not be coded as it was a given in their student assignment sample. As shown in greater detail in Table 1, the six codes adopted in this model were thus (i) attending to feelings, (ii) association, (iii) integration, (iv) validation, (v) appropriation, and (vi) outcome of reflection. In the tradition of Wong et al. (1991) the students in the sample were categorised into the three main categories of (i) non-reflectors, (ii) reflectors, and (iii) critical reflectors. Non-reflectors did not show any evidence of reflective thinking although they may attend to feelings. Reflectors showed elements of reflection (i.e., association, integration, validation, and/or appropriation) but did not show any "critical changes to perspective" (Wong et al., 1995). Critical reflectors, on the other hand, had the elements shown by reflectors but also showed changes to perspectives. It should be noted that Wong et al. (1995) utilised a two-level analysis whereby after they had coded the students' reflective papers in the sample according to the six codes above and classified the students as non-reflectors, reflectors or critical reflectors, they coded the students again using the student as the unit of coding instead of the paragraphs of students' written work. In this second level of coding, they managed to obtain high reliability scores and agreement as to whether students should be classified as non-reflectors, reflectors or critical reflectors. While reliability of coding was attained for the second level of coding by Wong et al. (1995) they admitted that they encountered problems in obtaining acceptable agreement levels among their five coders for the first level of coding.

Data showing evidence of reflective thought is usually obtained from many sources, including questionnaires, interviews, workshops, exams, academic papers, and workshops (Dyment and O'Connell, 2011). While data can be collected from many sources, past studies have shown that the learning journal appears to be a common and popular choice (Forrest, 2008; Bell et al., 2011; Abednia et al., 2013; Donohoe, 2015). Wong et al. (1995) called reflective journals a "valid tool for assessing students' accomplishment of learning" and Donohoe (2015) felt that the students' reflective thinking could be detected through them. 
Table-1. Summary of coding models to assess reflective thinking

\begin{tabular}{|c|c|c|}
\hline ree-stage model & 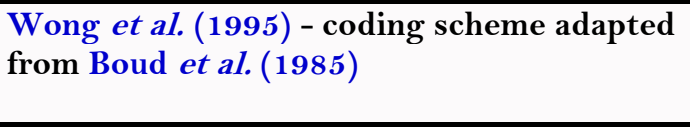 & $\begin{array}{l}\text { Kember et al. (2008) - four- } \\
\text { ategory model to assess written } \\
\text { vork }\end{array}$ \\
\hline $\begin{array}{l}\text { Return to experience } \\
\text { - The learner returns to and } \\
\text { recaptures the experience in } \\
\text { context in full impact. } \\
\text { - The learner mentally revisits } \\
\text { and vividly portrays the focus } \\
\text { experience. } \\
\text { Attending to feelings } \\
\text { - Learners focus on the feelings } \\
\text { and emotions which were/are } \\
\text { present. } \\
\text { These feelings can inhibit or } \\
\text { enhance possibilities for } \\
\text { further reflection and learning. } \\
\text { - Negative feelings } \\
\text { discharged and positive ones } \\
\text { can be celebrated. } \\
\text { Re-evaluation of experience } \\
\text { - This includes the four aspects } \\
\text { of association, integration, } \\
\text { validation, and appropriation. } \\
\text { - Association - relating new } \\
\text { information with what is } \\
\text { already known. } \\
\text { - Integration - } \\
\text { relationships between new and } \\
\text { old information. } \\
\text { - } \text { - Allidation - determining the } \\
\text { authenticity for the learner of } \\
\text { the ideas and feelings which } \\
\text { harts of a whole. } \\
\text { making the knowledge one's } \\
\text { own and part of one's normal } \\
\text { ways of operating. } \\
\text { - }\end{array}$ & 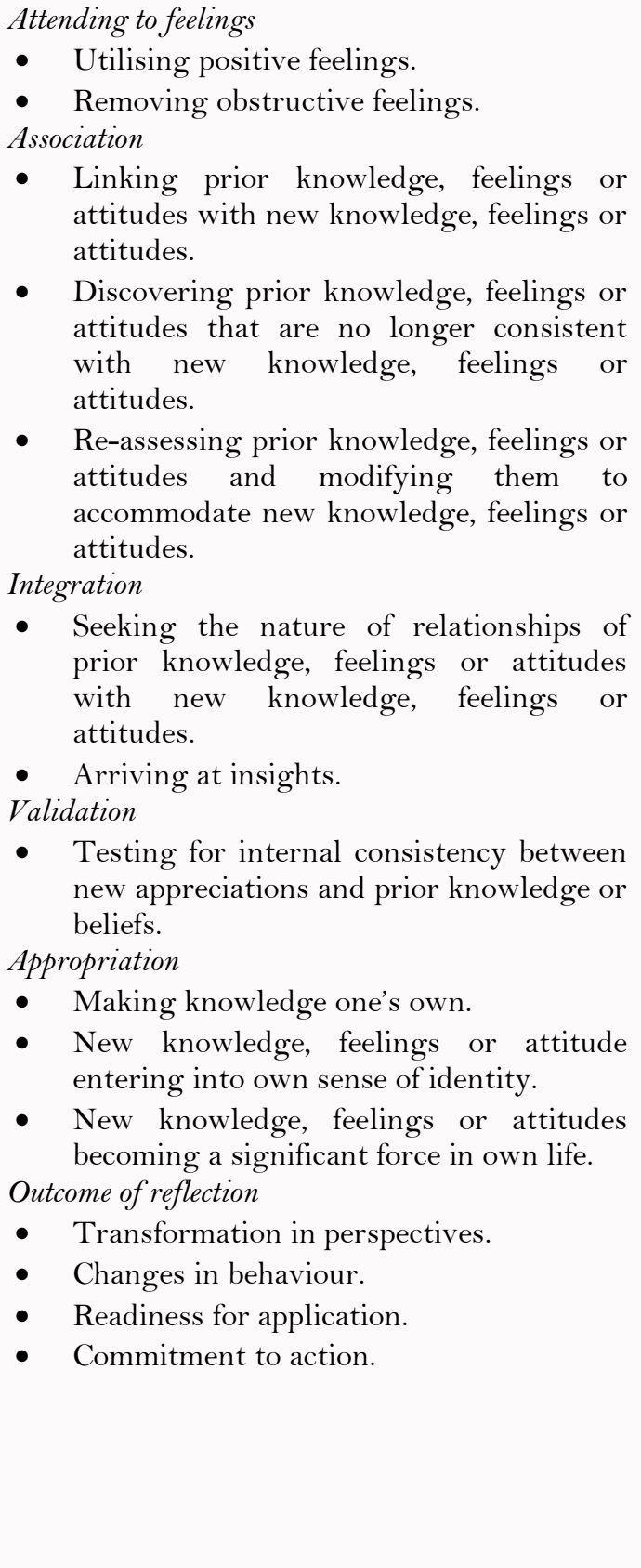 & 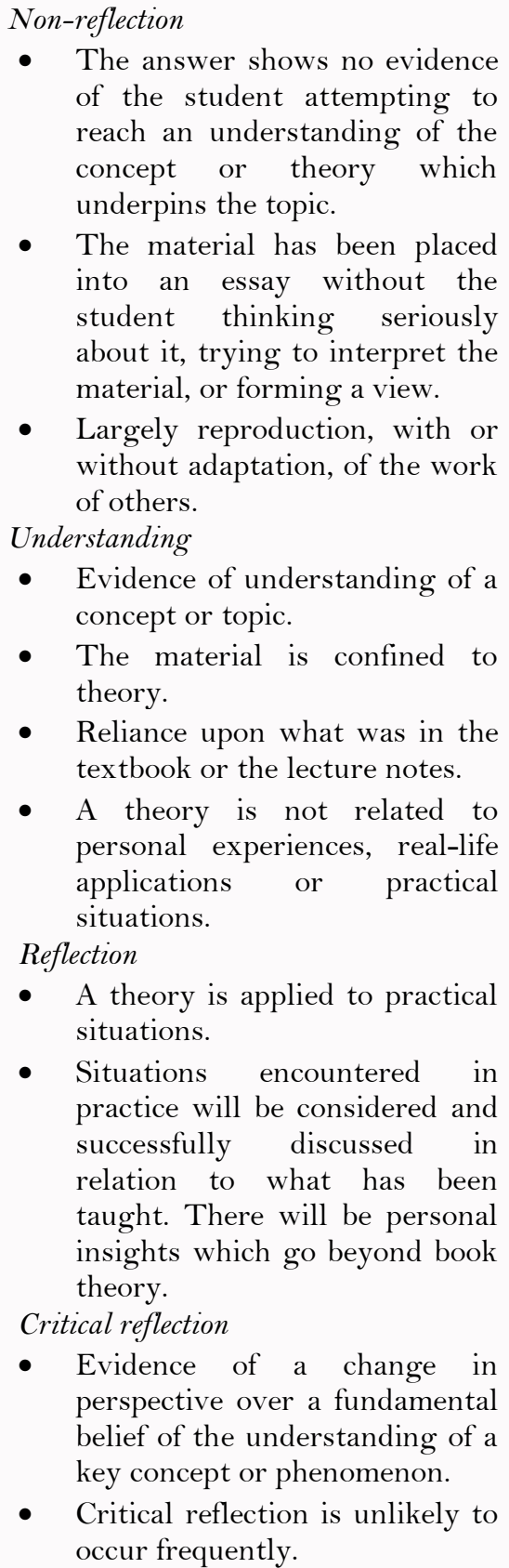 \\
\hline
\end{tabular}

In terms of the sample size, Dyment and O'Connell (2011) found that studies into reflective thought over the period of 1995-2009 utilised samples of between 15 to 79 respondents. In most qualitative analyses, the validity of data analyses is an important consideration. Most studies used a minimum of two assessors although studies using one assessor only have also been reported. Where two or more assessors or coders are used in studies, often, interrater reliability scores are provided to indicate the levels of agreement between and among assessors although the scores have varied between low $(r=0.50)$ and high $(r=0.88)$ acceptability levels (Dyment and O'Connell, 2011).

Table-2. Levels of learners' reflective thinking found in past research

\begin{tabular}{l|l|l|l}
\hline $\begin{array}{l}\text { Past } \\
\text { research }\end{array}$ & Plack et al. (2005) & Thorpe (2004) & Wong et al. (1995) \\
\hline Sample & Physical therapy students in the USA & Nursing students in Canada & $\begin{array}{l}\text { Nursing students in } \\
\text { Hong Kong }\end{array}$ \\
\hline Results & (i) No evidence of reflection (14.7\%) & (i) Non-reflectors (38.46\%) & (i) Non-reflectors \\
& (ii) Evidence of reflection (43.7\%) & (ii) Reflectors (50\%) & $(13.3 \%)$ \\
& (iii) Evidence of critical reflection (41.9\%) & (iii) Critical reflectors (11.54\%) & (ii) Reflectors (75.6\%) \\
& & & (iii) Critical reflectors \\
& & & $(11.1 \%)$
\end{tabular}

Source: Wong et al. (1995); Thorpe (2004) and Plack et al. (2005)

In studies which have attempted to classify learners into non-reflectors, reflectors, and critical reflectors, results have been mixed in different fields. Plack et al. (2005) studied 27 physical therapy students in the USA, Thorpe (2004) studied 52 nursing students in Canada and Wong et al. (1995) studied 45 nursing students in Hong Kong. The results of these studies and their subsequent classification of levels of students' reflective thinking are summarised in Table 2. Overall, reflectors tend to make up the largest group of learners in each of the past research reported in Table 2. However, there is insufficient data from other studies to make further meaningful generalisations regarding this. The data from this study will contribute to this area by adding to the literature. 


\section{Methodology}

\subsection{Data Collection Method}

This study is focused on the aspect of planned and deliberate learning, which is "learning which is intentional in which learners are aware that they are learning; learning with a definite, specific goal rather than generalized learning” (Boud et al., 1985). The study was conducted in Kota Kinabalu, Sabah, Malaysia. Prior to data collection, the respondents involved in this study were given an explanation of the purpose and design of the data collection process. The sample was obtained in 2015 from a class of undergraduate students taking an English for Specific Purposes (ESP) course. The students were enrolled in the Bachelor of Accountancy (Hons) programme at the university and took the ESP course Communication and Interpersonal Skills, which was under the purview of the Academy of Language Studies at the university. Instructors met the students for face-to-face interaction two hours a week for a total of 14 weeks. The course aimed to equip students with the communication and interpersonal skills to perform well at job interviews.

The first part of the course required students to analyse their own strengths and weaknesses, qualifications, and achievements as part of their preparation for employment. This part of the course became the focus of the inquiry. Students were given a prompt in a self-exploration exercise during one of the face-to-face meetings in class with the instructors. To facilitate this self-exploration exercise, the instructors used a prompt taken from Downes (2008) which was actually a game that provided various self-exploratory questions. Students were divided into groups of four and were allowed to play this game over a two-hour session. Prior to the start of the game, the instructor explained to students the learning objective of the activity. The instructor also briefed students about the need to write down their thoughts about the exercise in a learning journal after the session. The flow of activities in this process corresponded with Boud (1994) model of learning, which consists of preparation, experience, and reflection (see Figure 1).

Throughout the 14-week semester, students were required to continuously journal their reflections and thoughts in the written journal. The only format given by the instructor was the headings for the journal which indicated the activities or experiences relevant to the course outcome. The students' written journals were collected by the instructor at the end of the course. For the purpose of this study, only the journal section which contained the students' reflections on the self-exploratory exercise was analysed. In total, all 37 students in the class participated in this study and submitted their reflective journals (RJ). All 37 journals were then randomly assigned a number, ranging from RJ1 (Reflective Journal 1) to RJ37 (Reflective Journal 37) for ease of discussion.

\subsection{Data Analysis Procedure}

In this study, only the section of the students' reflective journal which outlined their reflections on the selfexploratory exercise was extracted for analysis. This section was easily identifiable due to the lines of demarcation provided by the section headings. However, an actual analysis of the sample showed that 15 (or $41.67 \%$ ) of the RJs were not written using the section headings provided by the instructors although they still contained the main elements. In cases where section headings were absent, the researchers extracted the required section through qualitative reading of the RJs.

After reviewing available literature, several coding schemes were found to be relevant to the current study. To determine which coding scheme was more suitable to analyse the data obtained, a pilot test using 5 student journals was conducted using the available coding schemes which the researchers felt might be suitable for this study (see Table 1). It was decided to adopt both models by Boud (1994) and Wong et al. (1995) for the purpose of this study. The decision to adapt these two models in this study was because they provided clear descriptions of their coding scheme, the models were oft-cited in literature and they appeared to fit in with the current study framework. The model by Wong et al. (1995) was actually adapted from Boud's earlier work but they omitted the first element of Boud's model, which was "return to experience". This was suitable for their sample but for the context of this study, the researchers decided to retain this element. The rest of the elements in Boud (1994) model (i.e., "attending to feelings" and "re-evaluation of experience") were adopted for this study as well. In this study, the category, "re-evaluation of experience" was taken as a whole and not separated into their individual elements (i.e., "association", "integration", "validation", and "appropriation”) as done by Wong et al. (1995) because the purpose of this study is to study the presence of reflective thinking and not to distinguish features of each element in-depth. This decision to not further sub-divide the "re-evaluation of experience" category is further reinforced by Boud (1994) comment that "these aspects should not be thought of as stages through which learners should pass, but parts of a whole". An additional category, "outcome of reflection" was added to reflect the critical reflection portion of the process. Thus, the four categories or elements of reflective thinking adopted in this current study are, (i) return to experience, (ii) attending to feelings, (iii) re-evaluation of experience, and (iv) outcome of reflection, and a summary of each element is shown in Table 3.

Table-3. Four-category model to assess reflective thinking

\begin{tabular}{l|l|l}
\hline Category code & Descriptor & \multicolumn{1}{|c}{ Summary } \\
\hline C1 & Return to experience & $\begin{array}{l}\text { The learner mentally recalls the experience and captures the focus of the } \\
\text { process. }\end{array}$ \\
\hline C2 & Attending to feelings & $\begin{array}{l}\text { The learner expresses positive and negative feelings as a result of the } \\
\text { experience. }\end{array}$ \\
\hline C3 & $\begin{array}{l}\text { Re-evaluation of } \\
\text { experience }\end{array}$ & $\begin{array}{l}\text { The learner reflects on the experience using prior knowledge and belief } \\
\text { systems. } \\
\text { This includes the four aspects of association, integration, validation, and } \\
\text { appropriation. }\end{array}$ \\
\hline C4 & Outcome of reflection & $\bullet \quad$ The learner demonstrates an intention to act on the result of reflection. \\
\hline
\end{tabular}

The principles of coding were also adapted from Wong et al. (1995) in general for the coding of reflective practices as well as from other established practices in qualitative analyses of written discourse. In this study, the 
unit of coding employed was the sentence (Holmes, 1997; Ozturk, 2007). However, in cases where there were compound and/or complex sentences, a T-unit was taken as the unit of analysis. A T- unit consists of a main/independent clause and any subordinate/dependent clause/s or non-clausal structure attached to or embedded in it (Ding, 2007; Sachs and Polio, 2007) Should adjacent sentences or T-units contain the same information required of the code, then these were coded once only. Only when shifts were noted would a different code be assigned. Data containing student thoughts on administrative issues were not coded and only points with substantial evidence were coded. Evidence was extracted qualitatively by reading the textual data using linguistic clues.

Once the coding was completed, a frequency count was done of every category $(\mathrm{C} 1, \mathrm{C} 2, \mathrm{C} 3$, and $\mathrm{C} 4)$ for each $\mathrm{RJ}$ in order for the second-coder reliability score to be calculated. To this end, both the first and second researchers discussed and agreed on the coding scheme during the pilot study. The second researcher then coded all the RJs, and the first researcher became the second coder. Using the reliability formula suggested by Wong et al. (1995) this process yielded a reliability score of 0.86 (i.e., $r=0.86$ ). In the coding process, students were assigned to the three categories of non-reflector, reflector, and critical reflector, as summarised in Table 4.

Table-4. Classification of students' level of reflection

\begin{tabular}{l|l}
\hline Level of reflection & Classification rules \\
\hline Non-reflector & $\begin{array}{l}\text { Shows none or up to the first two categories (C1 and/or C2, which are "return to } \\
\text { experience" and "attending to feelings") of the four categories of reflective thinking }\end{array}$ \\
\hline Reflector & $\begin{array}{l}\text { Shows evidence of the third category "re-evaluation of experience" (C3), with or without } \\
\text { the first two categories ("return to experience" and/or "attending to feelings") }\end{array}$ \\
\hline Critical reflector & - Has features of a reflector but also shows evidence of "outcome of reflection" (C4) \\
\hline
\end{tabular}

It should be noted that the second level of coding done by Wong et al. (1995) was not done as the researchers deemed that the first level of coding was sufficient for the purpose of this study. In addition, past researchers have accepted results using one level of coding (Dyment and O'Connell, 2011) while other researchers have found the two-level coding process "harder to employ" (Kember et al., 2008).

Table-5. Frequency of each category of reflection and classification of level of reflection

\begin{tabular}{|c|c|c|c|c|c|}
\hline \multirow[t]{2}{*}{$\mathbf{R J}$} & \multicolumn{4}{|c|}{ Frequency of each category of reflective thinking } & \multirow{2}{*}{$\begin{array}{l}\text { Classification of the } \\
\text { level of reflection }\end{array}$} \\
\hline & $\begin{array}{l}\text { C1 - Return to } \\
\text { experience }\end{array}$ & $\begin{array}{l}\text { C2 - Attending } \\
\text { to feelings }\end{array}$ & $\begin{array}{l}\text { C3 - Re-evaluation of } \\
\text { experience }\end{array}$ & $\begin{array}{l}\text { C4-Outcome of } \\
\text { reflection }\end{array}$ & \\
\hline 1 & 2 & 1 & 2 & $\mathrm{O}$ & Reflector \\
\hline 2 & 2 & $\mathrm{O}$ & 3 & 1 & Critical reflector \\
\hline 3 & 1 & $\mathrm{O}$ & 1 & $\mathrm{O}$ & Reflector \\
\hline 4 & 2 & $\mathrm{O}$ & 2 & 1 & Critical reflector \\
\hline 5 & 1 & 1 & 1 & $\mathrm{O}$ & Reflector \\
\hline 6 & $\mathrm{O}$ & $\mathrm{O}$ & $\mathrm{O}$ & $\mathrm{O}$ & Non-reflector \\
\hline 7 & 1 & 1 & 1 & $\mathrm{O}$ & Reflector \\
\hline 8 & 1 & 1 & 1 & $\mathrm{O}$ & Reflector \\
\hline 9 & $\mathrm{O}$ & 1 & 1 & $\mathrm{O}$ & Reflector \\
\hline 10 & 1 & $\mathrm{O}$ & 1 & 1 & Critical reflector \\
\hline 11 & 1 & 1 & 1 & $\mathrm{O}$ & Reflector \\
\hline 12 & 1 & 1 & 1 & 1 & Critical reflector \\
\hline 13 & 2 & $\mathrm{O}$ & 1 & $\mathrm{O}$ & Reflector \\
\hline 14 & 3 & 1 & 4 & $\mathrm{O}$ & Reflector \\
\hline 15 & $\mathrm{O}$ & $\mathrm{O}$ & $\mathrm{O}$ & $\mathrm{O}$ & Non-reflector \\
\hline 16 & 1 & $\mathrm{O}$ & 1 & $\mathrm{O}$ & Reflector \\
\hline 17 & $\mathrm{O}$ & $\mathrm{O}$ & $\mathrm{O}$ & $\mathrm{O}$ & Non-reflector \\
\hline 18 & 2 & 1 & 1 & $\mathrm{O}$ & Reflector \\
\hline 19 & 1 & 2 & 1 & $\mathrm{O}$ & Reflector \\
\hline 20 & $\mathrm{O}$ & $\mathrm{O}$ & 1 & $\mathrm{O}$ & Reflector \\
\hline 21 & $\mathrm{O}$ & 1 & 1 & $\mathrm{O}$ & Reflector \\
\hline 22 & 1 & $\mathrm{O}$ & 1 & $\mathrm{O}$ & Reflector \\
\hline 23 & 2 & $\mathrm{O}$ & 3 & $\mathrm{O}$ & Reflector \\
\hline 24 & $\mathrm{O}$ & $\mathrm{O}$ & 1 & $\mathrm{O}$ & Reflector \\
\hline 25 & $\mathrm{O}$ & 1 & 1 & $\mathrm{O}$ & Reflector \\
\hline 26 & $\mathrm{O}$ & $\mathrm{O}$ & 1 & $\mathrm{O}$ & Reflector \\
\hline 27 & 2 & 1 & 1 & $\mathrm{O}$ & Reflector \\
\hline 28 & 1 & $\mathrm{O}$ & $\mathrm{O}$ & $\mathrm{O}$ & Non-reflector \\
\hline 29 & 1 & $\mathrm{O}$ & 1 & $\mathrm{O}$ & Reflector \\
\hline 30 & $\mathrm{O}$ & $\mathrm{O}$ & 1 & 1 & Critical reflector \\
\hline 31 & $\mathrm{O}$ & 2 & 1 & 2 & Critical reflector \\
\hline 32 & 1 & 1 & 1 & $\mathrm{O}$ & Reflector \\
\hline 33 & $\mathrm{O}$ & 1 & 1 & $\mathrm{O}$ & Reflector \\
\hline 34 & 1 & 1 & 2 & $\mathrm{O}$ & Reflector \\
\hline 35 & $\mathrm{O}$ & $\mathrm{O}$ & 1 & $\mathrm{O}$ & Reflector \\
\hline 36 & $\mathrm{O}$ & $\mathrm{O}$ & 1 & $\mathrm{O}$ & Reflector \\
\hline 37 & $\mathrm{O}$ & $\mathrm{O}$ & 1 & $\mathrm{O}$ & Reflector \\
\hline
\end{tabular}




\section{Results and Discussion}

Each category of reflective thinking was found to be present in the sample but they appeared with differing frequencies. Table 5 shows the frequency count of each category of reflection for each RJ, Table 6 shows textual examples for each category and Table 7 provides a comparison of the current research results with the results of past studies. The results show that 4 students $(10.8 \%)$ were non-reflectors, 27 students $(73.0 \%)$ were reflectors and 6 students $(16.2 \%)$ were critical reflectors. This effectively provides answers to the research question outlined earlier regarding the level of reflective thinking attained by a particular group of students at the Sabah branch of MARA University of Technology.

Table-6. Examples of textual data for each category

\begin{tabular}{|c|c|c|c|c|}
\hline Category & \multicolumn{4}{|c|}{ Examples of textual data } \\
\hline $\begin{array}{l}\text { C1 } \quad- \\
\text { Return to } \\
\text { experience }\end{array}$ & \multicolumn{4}{|c|}{$\begin{array}{l}\text { At first, I am (sic) not serious in answering the questions and try to make jokes out of it. (RJ12) } \\
\text { During the first week of lecture, we played a board game. The game was filled with questions } \\
\text { about ourselves. It might sound simple but the truth is, I could not really answer the questions. } \\
\text { (RJ13) } \\
\text { We form (sic) a group and we play (sic) the game by turn using a dice. (RJ14) }\end{array}$} \\
\hline $\begin{array}{l}\mathrm{C}_{2}- \\
\text { Attending } \\
\text { to feelings }\end{array}$ & \multicolumn{4}{|c|}{$\begin{array}{l}\text { But what I am worried the most now, right afte } \\
\text { quite shocked for not knowing deeply about my c } \\
\text { At first, of course, it was disappointing. (RJ34) }\end{array}$} \\
\hline $\begin{array}{l}\text { C3 - Re- } \\
\text { evaluation } \\
\text { of } \\
\text { experience }\end{array}$ & \multicolumn{4}{|c|}{$\begin{array}{l}\text { I also never thought about asking my friends what they think about me (RJ12) } \\
\text { It made me think about myself more. Honestly, I don't really know much about myself. (RJ22) } \\
\text { Ermm, } 22 \text { years living in this world yet, I know nothing about myself? I'm wondering what I had } \\
\text { done for the past } 22 \text { years of my life. (RJ23) }\end{array}$} \\
\hline $\begin{array}{l}\mathrm{C} 4 \quad- \\
\text { Outcome of } \\
\text { reflection }\end{array}$ & \multicolumn{4}{|c|}{$\begin{array}{l}\text { I started to list my strengths and weaknesses and I realized I have many strengths but I didn't (sic) } \\
\text { aware that it (sic) will help me to get employed. (RJ2) } \\
\text { Besides that, I also started to ask my family and friends about my strengths and weaknesses. } \\
\text { (RJ12) } \\
\text { Then, I took an initiative to sit alone and think about who am I (sic)... Then, I was struggling by } \\
\text { searching in (sic) the internet on how to know better about myself. I play on (sic) the games and } \\
\text { quiz (sic) provided just to know about myself...(RJ31) }\end{array}$} \\
\hline Researchers & This current study & Plack et al. (2005) & Thorpe (2004) & Wong et al. (1995) \\
\hline Sample & $\begin{array}{l}\text { Accounting students } \\
\text { in Malaysia }\end{array}$ & $\begin{array}{l}\text { Physical therapy students in } \\
\text { the USA }\end{array}$ & $\begin{array}{l}\text { Nursing students in } \\
\text { Canada }\end{array}$ & $\begin{array}{l}\text { Nursing students in } \\
\text { Hong Kong }\end{array}$ \\
\hline Results & $\begin{array}{l}\text { Non-reflectors } \\
(10.8 \%) \\
\text { Reflectors }(73.0 \%) \\
\text { Critical reflectors } \\
(16.2 \%)\end{array}$ & $\begin{array}{l}\text { No evidence of reflection } \\
(14.7 \%) \\
\text { Evidence of reflection }(43.7 \%) \\
\text { Evidence of critical reflection } \\
(41.9 \%)\end{array}$ & $\begin{array}{l}\text { Non-reflectors } \\
(38.46 \%) \\
\text { Reflectors }(50 \%) \\
\text { Critical reflectors } \\
(11.54 \%)\end{array}$ & $\begin{array}{l}\text { Non-reflectors }(13.3 \%) \\
\text { Reflectors }(75.6 \%) \\
\text { Critical } \\
(11.1 \%)\end{array}$ \\
\hline
\end{tabular}

It can be seen that in general, for all the studies being compared, reflectors tend to dominate the sample. In the current sample, reflectors accounted for the largest percentage at $73.0 \%$. However, it is interesting to note that there were more critical reflectors in the current sample of accounting students compared to Wong et al. (1995) and Thorpe (2004) samples of nursing students. Even so, when compared with the work of Plack et al. (2005), there were more critical reflectors among physical therapy students in the USA as their sample yielded $41.9 \%$ critical reflectors.

Although at varying degrees, it appears that results obtained from the current sample of study more closely resemble those from a sample of physical therapy students in the USA whereby the smallest group are the nonreflectors, the largest group are the reflectors and critical reflectors make up the second largest group. In nursing, however, the smallest group are the critical reflectors. The results of this study have allowed more comparisons to be made in this sense and have opened up other possibilities for future research into this area.

\section{Conclusion}

This study is the first of its kind to provide preliminary information regarding the reflective thinking levels in accounting undergraduates in Sabah, Malaysia. The findings of this study have contributed to the field by adding to the literature on reflective thinking. Once practitioners are aware of the reflective thinking levels of students and how these thought processes contribute towards their acquisition of skills, classroom instruction can be finetuned to tailor to the needs of different students in order to encourage transformative learning. Pedagogical concerns may also be addressed with a view towards the actual reflective processes which the students go through. The results of this research can provide the first step towards an inquiry in that direction.

A comparison of the results of this study with those of similar past studies has also raised various interesting questions with regard to explorations in reflective thinking. One of these questions is whether the different fields of study may be producing students with different reflective thinking ability. Another question is whether the different localities and thus backgrounds of the students in the sample have contributed to the reflective thinking abilities of the students. While these two questions open up many possibilities for further exploration, another inevitable inquiry is whether different methods of assessing critical reflection may yield different results. Further comparative studies are needed to provide more insight into these questions. It would also be of interest to examine further avenues of research related to this such as by using a different sample of students (i.e., those from a different undergraduate programme) undertaking a similar ESP course if they are available. Other than that, the further indepth inquiry can be explored by interviewing the students to gather more support for the conclusions reached in this study. 


\section{References}

Abednia, A., A. Hovassapian, S. Teimournezhad and N. Ghanbari, 2013. Reflective journal writing: Exploring in-service EFL teachers' perception. System, 41(3): 503-5 14. View at Google Scholar $\mid$ View at Publisher

Basol, G. and I.E. Gencel, 2013. Reflective thinking scale: A validity and reliability study. Educational Sciences Theory and Practice, 13(2): 941-946. View at Google Scholar

Bell, A., J. Kelton, N. McDonagh, R. Mladenovic and K. Morrison, 2011. A critical evaluation of the usefulness of a coding scheme to categorise levels of reflective thinking. Assessment and Evaluation in Higher Education, 36(7): 797-815. View at Google Scholar $\mid$ View at Publisher

Boud, D., 1994. Conceptualising learning from experience: Developing a model for facilitation. Proceedings of the 35 th Adult Education Research Conference. Paper Presented at the 35th Adult Education Research Conference, Knoxville, Tennessee. Tennessee: University of Tennessee. pp: 49-54

Boud, D., R. Keogh and D. Walker, 1985. Reflection: Turning experience into learning. New York: Nichols Publishing Company.

Casey, T., 2013. Reflective practice in legal education: The stages of reflection. Clinical Law Review, 20(2): 317-354. View at Google Scholar

Chittooran, M.M., 2015. Reading and writing for critical reflective thinking. New Directions for Teaching and Learning, 143: 79-95. View at Google Scholar |View at Publisher

Dewey, J., 1933. How we think: A restatement of the relation of reflective thinking to the educative process. New York: D.C. Heath and Company.

Ding, H., 2007. Genre analysis of personal statements: Analysis of moves in application essays to medical and dental schools. English for Specific Purposes, 26(3): 368-392. View at Google Scholar | View at Publisher

Donohoe, A., 2015. Reflective writing: Articulating an alternative pedagogy. Procedia Social and Behavioural Sciences, 186: 800-804. View at Google Scholar | View at Publisher

Downes, C., 2008. Cambridge english for job-hunting. Cambridge: Cambridge University Press.

Dyment, J.E. and T.S. O'Connell, 2011. Assessing the quality of reflection in student journals: A review of the research. Teaching in Higher Education, 16(1): 81-97. View at Google Scholar $\mid$ View at Publisher

Forneris, S.G. and C. Peden-McAlpine, 2007. Evaluation of a reflective learning intervention to improve critical thinking in novice nurses. Journal of Advanced Nursing, 57(4): 410-421. View at Google Scholar | View at Publisher

Forrest, M.E.S., 2008. On becoming a critically reflective practitioner. Health Information and Libraries Journal, 25(3): 229-232. View at Google Scholar $\mid$ View at Publisher

Holmes, R., 1997. Genre analysis and the social sciences: An investigation of the structure of research article discussion sections in three disciplines. English for Specific Purposes, 16(4): 32 1-337. View at Google Scholar | View at Publisher

Kayapinar, U., 2016. A study on reflection in in-service teacher development: Introducing reflective practitioner development model. Educational Sciences Theory and Practice, 16(5): 1671-1691. View at Google Scholar $\mid$ View at Publisher

Kember, D., 1999. Determining the level of reflective thinking from students' written journals using a coding scheme based on the work of Mezirow. International Journal of Lifelong Education, 18(1): 18-30. View at Google Scholar $\mid$ View at Publisher

Kember, D., J. McKay, K. Sinclair and F.K.Y. Wong, 2008. A four-category scheme for coding and assessing the level of reflection in written work. Assessment and Evaluation in Higher Education, 33(4): 369-379. View at Google Scholar $\mid$ View at Publisher

Lyons, N., 2010. Reflection and reflective inquiry: Critical issues, evolving conceptualizations, contemporary claims and future possibilities. In Lyons, N. (Ed.), Handbook of reflection and reflective inquiry: Mapping a way of knowing for professional reflective inquiry. New York: Springer. pp: 3-22.

Mezirow, J., 2000. Learning to think like an adult: Core concepts of transformation theory. In Mezirow, J. \& Associates (Eds.), Learning as transformation. California: Jossey-Bass Inc. pp: 3-34.

Naghdipour, B. and O.L. Emeagwali, 2013. Assessing the level of reflective thinking in ESL students. Procedia Social and Behavioural Sciences, 83: 266-271. View at Google Scholar |View at Publisher

Ozturk, I., 2007. The textual organization of research article introductions in applied linguistics: Variability within a single discipline. English for Specific Purposes, 26(1): 25-38. View at Google Scholar | View at Publisher

Plack, M.M., M. Driscoll, S. Blissett, R. McKenna and T.P. Plack, 2005. A method for assessing reflective journal writing. Journal of Allied Health, 34(4): 199-208. View at Google Scholar

Sachs, R. and C. Polio, 2007. Learners' uses of two types of written feedback on a L2 writing revision task. Studies in Second Language Acquisition, 29(1): 67-100. View at Google Scholar | View at Publisher

Schon, D., 1983. The reflective practitioner: How professionals think in action. New York: Basic Books.

Thorpe, K., 2004. Reflective learning journals: From concept to practice. Reflective Practice, 5(3): 327-343. View at Google Scholar $\mid$ View at Publisher

Wium, A. and S.D. Plessis, 2016. The usefulness of a tool to assess reflection in a service-learning experience. African Journal of Health Professions Education, 8(2): 178-183. View at Google Scholar | View at Publisher

Wong, F.K., D. Kember, L.Y. Chung and L.Y. CertEd, 1990. How critical reflection triggers transformative learning. In Mezirow, J. \& Associates (Eds.), Fostering critical reflection in adulthood. California: Jossey-Bass Inc. pp. 1-20.

Wong, F.K., D. Kember, L.Y. Chung and L.Y. CertEd, 1991. Assessing the level of student reflection from reflective journals. Journal of Advanced Nursing, 22(1): 48-57. View at Google Scholar | View at Publisher

Wong, F.K.Y., D. Kember, L.Y.F. Chung and L. Yan, 1995. Assessing the level of student reflection from reflective journals. Journal of Advanced Nursing, 22(1): 48-57. View at Google Scholar | View at Publisher 